\title{
Studi Keanekaragaman Jenis Serangga Daerah Bekas Kebakaran Pada Kawasan Hutan Lindung Bukit Luwit Kecamatan Kelam Permai Kabupaten Sintang
}

\author{
Antonius \\ Fakultas Pertanian Universitas Kapuas Sintang \\ email: anton1975_gurung@yahoo.co.id
}

\begin{abstract}
Abstraks : Penelitian ini bertujuan Untuk mengetahui untuk mendapatkan informasi tentang keanekaragaman jenis serangga yang terdapat di hutan Lindung Bukit Luwit Kecamatan Kelam Permai Kabupaten Sintang. Metode yang digunakan dalam penelitian adalah metode survei melalui inventarisasi langsung di lapangan. Metode inventarisasi yang dilakukan dengan membuat plot transek pengamatan berukuran $20 \times 20 \mathrm{~m}, 10 \times 10 \mathrm{~m}$, dan $5 \times 5 \mathrm{~m}$. Penelitian dilakukan pada waktu pukul 08.00-12.00 WIB, dilanjutkan pukul 13.00-15.00 WIB. Pengambilan pada waktu tersebut berdasarkan pertimbangan waktu serangga aktif. Hasil penelitian menunjukkan bahwa Indeks keanekaragaman jenis tertinggi terdapat spesies Leptocorisa sp dengan nilai ID 0,225, selanjutnya Anopheles $s p$ dengan nilai ID 0,155; Acherontia sp dengan nilai ID 0,042; Tenodora sp dengan nilai ID 0,029; Tenodora sp dengan nilai ID 0,024; Glossina sp dengan nilai ID 0,018; dan terendah adalah Aesha sp dengan nilai ID 0,012. Dominansi jenis tertinggi terdapat pada jenis spesies Leptocorisa sp dengan nilai 0,538 dan terendah spesies Aesha sp dengan nilai 0,005. Nilai densitas tertinggi yaitu spesies Leptocorisa sp dengan nilai Densitas 60,56; spesies Anopheles sp dengan nilai Densitas 30,85 dan spesies Acherontia sp dengan nilai Densitas 5,17. Nilai densitas terendah yaitu 1,82 pada spesies Aesha sp.; 2,49 pada spesies Glossina sp; 3,08 pada spesies Leptocarisa sp dan Tenodora sp; dan nilai Densitas sedang adalah spesies Tenodora $s p$ dengan nilai 3,64. Nilai densitas digolongkan tinggi bila nilai densitas $>5$. Untuk nilai densitas dikategorikan sedang bila berada pada kisaran 3,5 - 5. Sedangkan tergolong rendah bila nilai densitas kurang dari 3,5.
\end{abstract}

Kata Kunci : Keanekaragaman Jenis Serangga dan Hutan Lindung

\section{PENDAHULUAN}

Hutan Lindung (Protection

Forest) merupakan kawasan hutan

yang telah ditetapkan oleh

pemerintah atau kelompok

masyarakat tertentu untuk dilindungi, agar fungsi-fungsi ekologis, terutama untuk perlindungan tata air dan kesuburan tanah tetap berjalan dan dinikmati oleh masyarakat sekitar. 
Studi Keanekaragaman Jenis Serangga Daerah Bekas Kebakaran Pada Kawasan Hutan Lindung Bukit Luwit Kecamatan Kelam Permai Kabupaten Sintang

Hutan yang telah mengalami semakin penting dengan tujuan degradasi atau perubahan yang utama untuk menggambarkan adanya mengarah kepada kerusakan yang berakibat pada ancaman berbagai makhluk hidup didalamnya, seperti terjadinya kerusakan ekologis, antara lain perubahan populasi serangga sebagai salah satu indicator untuk menentukan kerusakan hutan.

Serangga merupakan bagian dari keanekaragaman hayati yang harus dijaga kelestariannya dari kepunahan maupun penurunan keanekaragaman jenisnya. Serangga memiliki nilai penting antara lain nilai ekologi, endemisme, konservasi, pendidikan, budaya, estetika, dan ekonomi (Little, 1957). Penyebaran serangga dibatasi oleh faktor-faktor geologi dan ekologi yang cocok, sehingga terjadi perbedaan keragaman jenis serangga. Perbedaan ini disebabkan adanya perbedaan iklim, musim, ketinggian tempat, serta jenis makanannya (Borror \& Long, 1998).

\begin{tabular}{llr}
\multicolumn{2}{c}{ Serangga } & merupakan \\
bioindikator & kesehatan & hutan. \\
Penggunaan & serangga & sebagai \\
bioindikator akhir-akhir ini dirasakan
\end{tabular}
keterkaitan dengan kondisi faktor biotik dan abiotik lingkungan (Speight et al. 1999). Sejumlah kelompok serangga seperti kumbang (terutama kumbang pupuk), semut, kupu-kupu dan rayap memberikan respons yang khas terhadap tingkat kerusakan hutan sehingga memiliki potensi sebagai spesies indikator untuk mendeteksi perubahan lingkungan akibat konversi hutan oleh manusia yang sekaligus menjadi indikator kesehatan hutan (Jones \& Eggleton, 2000). Dilain pihak, Kalimantan Barat merupakan salah satu wilayah di Indonesia yang memiliki laju deforestasi cukup tinggi. Deforestasi ini sebenarnya telah lama berlangsung akibat tekanan ekonomi, pembangunan infrastruktur, yang berdampak pada praktek illegal logging, kebakaran hutan dan lahan.

Pengendalian hayati pada dasarnya adalah pemanfaatan dan penggunaan musuh alami untuk mengendalikan populasi hama yang merugikan. Pengendalian hayati 
Studi Keanekaragaman Jenis Serangga Daerah Bekas Kebakaran Pada Kawasan Hutan Lindung Bukit Luwit Kecamatan Kelam Permai Kabupaten Sintang

sangat dilatar belakangi oleh tentang keanekaragaman jenis pengendalian alami dan serangga yang terdapat di hutan keseimbangan ekosistem. Jika suatu Lindung Bukit Luwit Kecamatan ekosistem terjadi keseimbangan Kelam Permai Kabupaten Sintang. maka kemungkinan ledakan populasi yang satu terhadap populasi lainnya tidak akan terjadi, atau sebaliknya penurunan populasi satu dengan populasi lainnya tidak akan terjadi. Seiring dengan kerusakan hutan yang salah satunya disebabkan oleh kebakaran hutan, maka akan berdampak terhadap keanekaragaman maupun populasi serangga secara keseluruhan disuatu kawasan hutan. Sebagaimana yang kemungkinan terjadi pada kawasan hutan lindung Bukit Luwit Kecamatan Kelam Permai Kabupaten Sintang yang telah mengalami fragmentasi akibat bencana kebakaran. Berdasarkan kondisi tersebut perlu dilakukan penelitian untuk mengetahui apakah akibat dari kebakaran kawasan hutan adat tersebut berdampak pada keseimbangan populasi serangga yang ada di dalamnya?

Tujuan dari penelitian ini adalah untuk mendapatkan informasi

\section{METODE PENELITIAN}

$\begin{array}{rrr}\text { Metode } & \text { penelitian yang } \\ \text { digunakan } & \text { adalah metode }\end{array}$
inventarisasi yang dilakukan dengan membuat plot pengamatan berukuran $20 \times 20 \mathrm{~m}, 10 \times 10 \mathrm{~m}$, dan $5 \times 5 \mathrm{~m}$. Penelitian dilakukan pada waktu pukul 08.00-12.00 WIB, dilanjutkan pukul 13.00-15.00 WIB. Melakukan penelitian pada waktu tersebut berdasarkan pertimbangan waktu serangga aktif.

Alat yang digunakan dalam penelitian ini berupa perangkap serangga, antara lain: Corong, jaring serangga, kamera, pisau lipat, botol Specimen. Bahan yang digunakan dalam penelitian ini, yaitu serangga yang dijumpai di lapangan, formalin untuk mengawetkan serangga yang tertangkap, kertas koran untuk tempat mengawetkan serangga.

Data yang diperoleh selanjutnya dianalisis dengan 
Studi Keanekaragaman Jenis Serangga Daerah Bekas Kebakaran Pada Kawasan Hutan Lindung Bukit Luwit Kecamatan Kelam Permai Kabupaten Sintang

menggunakan indeks

$\mathrm{R}_{1}=\frac{\mathrm{S}-1}{\ln \mathrm{N}}$

dominansi [D] dan indeks kesamaan jenis [IS].

$$
\begin{gathered}
\mathrm{ID}=\mathrm{H}^{\prime}=-\sum(\mathrm{ni} / \mathrm{N}) \log (\mathrm{ni} / \mathrm{N}) \\
\mathrm{i}=1
\end{gathered}
$$

\section{Keterangan:}

$\mathrm{R}_{1} \quad=$ Indeks kekayaan jenis

$\mathrm{S} \quad=$ Jumlah jenis

$\mathrm{N} \quad=$ Jumlah individu

Keterangan:

Indeks kekayaan Margalleft

$\mathrm{N}$ = Jumlah total seluruh jenis serangga

$\mathrm{ni} \quad=$ Jumlah tiap jenis serangga

$\mathrm{H}^{\prime}=$ Indeks keanekaragaman Shannon-Wiener

Untuk menentukan spesies yang dominan di dalam kawasan penelitian digunakan rumus indeks dominansi [D] Simpson

$\mathrm{D}=\sum \mathrm{pi}^{2}$, dimana pi adalah ni/N

Keterangan :

$\mathrm{Ni}=$ jumlah tiap jenis serangga

$\mathrm{N}=$ jumlah total seluruh species

$\mathrm{D}=$ indeks dominansi

Densitas atau Kekayaan Jenis

Pengukuran kekayaan jenis dalam plot pengamatan, pendekatan yang digunakan adalah Indeks kekayaan jenis dengan persamaan sebagai berikut :

$\left(\mathrm{R}_{1}\right)$ adalah indeks yang menunjukkan kekayaan jenis suatu komunitas, dimana besarnya nilai ini dipengaruhi oleh banyaknya jenis dan jumlah individu pada areal tersebut. Besaran $\mathrm{R}_{1}<3,5$ menunjukkan kekayaan jenis tergolong rendah, $\mathrm{R}_{1}=3,5-5,0$ menunjukkan kekayaan jenis tergolong sedang dan $\mathrm{R}_{1}>5,0$ tergolong tinggi.

\section{HASIL DAN PEMBAHASAN}

\section{Keanekaragaman Jenis}

Hasil analisis data berdasarkan jumlah dan jenis yang dijumpai di lapangan. Berikut jenis-jenis serangga yang ditemukan di lapangan selama kegiatan penelitian berlangsung di Kawasan Hutan Lindung Bukit Luwit Kecamatan Kelam Permai Kabupaten Sintang. 
Studi Keanekaragaman Jenis Serangga Daerah Bekas Kebakaran Pada Kawasan Hutan Lindung Bukit Luwit Kecamatan Kelam Permai Kabupaten Sintang

Tabel Jenis Serangga Di Kawasan Hutan Lindung Bukit Luwit

\begin{tabular}{|l|l|l|l|l|l|}
\hline $\begin{array}{c}\text { N } \\
\text { o }\end{array}$ & \multicolumn{1}{|c|}{$\begin{array}{c}\text { Nama } \\
\text { Daerah }\end{array}$} & \multicolumn{1}{|c|}{ Ordo } & \multicolumn{1}{|c|}{ Famili } & \multicolumn{1}{|c|}{ Spesies } & Jumlah \\
\hline 1 & Kupu-kupu & Lepidoptera & Papilionidae & Acherontia $s p$ & 15 \\
\hline 2 & Belalang & Orthoptera & Acrididae & Tenodora $s p$ & 7 \\
\hline 3 & Belalang & Orthoptera & Tettigoniidae & Tenodora $s p$ & 9 \\
\hline 4 & Kesak & Hymenoptera & Formicidae & Leptocorisa sp & 357 \\
\hline 5 & Kebensi & Odonata & Aeshnidae & Aesha $s p$ & 3 \\
\hline 6 & Nyamuk & Diptera & Culicidae & Anopheles $s p$ & 157 \\
\hline 7 & Lalat & Diptera & Muscidae & Glossina $s p$ & 5 \\
\hline 8 & Pitak & Hymenoptera & Vespidae & Leptocorisa $s p$ & 7 \\
\hline Jumlah & & & & $\mathbf{5 6 0}$ \\
\hline
\end{tabular}

Data Hasil Penelitian, 2018

Indeks Keanekaragaman Jenis (ID

$=\mathbf{H})$

Indeks Keanekaragaman Jenis

$(\mathrm{ID}=\mathrm{H})$ serangga berdasarkan hasil

penelitian di kawasan hutan lindung

Bukit Luwit yang sebagian telah mengalami kebakaran diperoleh ideks keanekaragaman jenis sebagai berikut.

Tabel Indeks Keanekaragaman Jenis Serangga Di Kawasan Hutan Lindung Bukit Luwit

\begin{tabular}{|l|l|l|c|l|}
\hline No & Nama Daerah & Famili & Jumlah & H' \\
\hline 1 & Kupu-kupu & Papilionidae & 15 & 0,042 \\
\hline 2 & Belalang a & Acrididae & 7 & 0,024 \\
\hline 3 & Belalang b & Tettigoniidae & 9 & 0,029 \\
\hline 4 & Kesak & Formicidae & 357 & 0,225 \\
\hline 5 & Kebensi & Aeshnidae & 3 & 0,012 \\
\hline 6 & Nyamuk & Culicidae & 157 & 0,155 \\
\hline 7 & Lalat & Muscidae & 5 & 0,018 \\
\hline 8 & Pitak & Vespidae & 7 & 0,024 \\
\hline & Jumlah & & $\mathbf{5 6 0}$ & \\
\hline
\end{tabular}

Sumber : Hasil Pengolahan Data, 2018

Indeks keanekaragaman jenis serangga tertinggi terdapat pada famili Formicidae sebesar 0,225; selanjutnya diikuti oleh famili PIPER No.28 Volume 15 April 2019
Culicidae sebesar 0,155; famili Papilionidae sebesar 0,042; famili Tettigoniidae sebesar 0,029; famili Acrididae dan famili Vespidae 
Studi Keanekaragaman Jenis Serangga Daerah Bekas Kebakaran Pada Kawasan Hutan Lindung Bukit Luwit Kecamatan Kelam Permai Kabupaten Sintang

masing-masing sebesar 0,024; famili Muscidae sebesar 0,018 dan terendah terdapat pada famili Aeshnidae sebesar 0,012. Tidak meratanya indeks keanekaragaman merupakan indikator keberadaan serangga di kawasan Hutan Lindung Bukit Luwit yang kondisinya sudah mengalami gangguan berupa bekas kebakaran hutan.

\section{Indeks Dominansi (D)}

Tabel Indeks Dominansi Jenis Serangga Di Kawasan Hutan Lindung Bukit Luwit

\begin{tabular}{|l|l|l|c|l|}
\hline No & Nama Daerah & Famili & Jumlah & D \\
\hline 1 & Kupu-kupu & Papilionidae & 15 & 0,027 \\
\hline 2 & Belalang a & Acrididae & 7 & 0,013 \\
\hline 3 & Belalang b & Tettigoniidae & 9 & 0,016 \\
\hline 4 & Kesak & Formicidae & 357 & 0,638 \\
\hline 5 & Kebensi & Aeshnidae & 3 & 0,005 \\
\hline 6 & Nyamuk & Culicidae & 157 & 0,280 \\
\hline 7 & Lalat & Muscidae & 5 & 0,009 \\
\hline 8 & Pitak & Vespidae & 7 & 0,013 \\
\hline & Jumlah & & $\mathbf{5 6 0}$ & $\mathbf{0 , 4 8 6}$ \\
\hline
\end{tabular}

Sumber: Hasil Analisa Data, 2018

Indeks Dominansi jenis serangga tertinggi terdapat pada famili Formicidae sebesar 0,638; selanjutnya diikuti oleh famili Culicidae sebesar 0,280; famili Papilionidae sebesar 0,027; famili Tettigoniidae sebesar 0,016; famili Acrididae dan famili Vespidae
Indeks dominansi dari beberapa jenis serangga merupakan gambaran keberadaan dominasi jenis serangga tertentu terhadap jenis serangga lainnya dalam suatu kawasan hutan. Dominansi jenis serangga yang dijumpai di lapangan selama penelitian berlangsung sebagaimana tertera pada tabel berikut ini. 
Studi Keanekaragaman Jenis Serangga Daerah Bekas Kebakaran Pada Kawasan Hutan Lindung Bukit Luwit Kecamatan Kelam Permai Kabupaten Sintang

Adanya jenis-jenis tertentu yang mendominasi menandakan bahwa di kawasan tersebut telah terjadi gangguan hutan yang menunjukkan kurangnya keseimbangan ekosistem penyusunnya.

\section{Indeks Kekayaan Jenis $\left(\mathbf{R}_{\mathbf{1}}\right)$}

Indeks kekayaan jenis dari beberapa jenis serangga merupakan gambaran kekayaan jenis serangga tertentu terhadap jenis serangga lainnya dalam suatu kawasan hutan. Berikut indeks kekayaan jenis serangga yang dijumpai di lapangan selama penelitian berlangsung sebagaimana tertera pada tabel berikut ini.

Tabel Indeks Kekayaan Jenis Serangga Di Kawasan Hutan Lindung Bukit Luwit

\begin{tabular}{|l|l|l|c|l|}
\hline No & Nama Daerah & Famili & Jumlah & $\mathbf{R}_{\mathbf{1}}$ \\
\hline 1 & Kupu-kupu & Papilionidae & 15 & 5,17 \\
\hline 2 & Belalang a & Acrididae & 7 & 3,08 \\
\hline 3 & Belalang b & Tettigoniidae & 9 & 3,64 \\
\hline 4 & Kesak & Formicidae & 357 & 60,56 \\
\hline 5 & Kebensi & Aeshnidae & 3 & 1,82 \\
\hline 6 & Nyamuk & Culicidae & 157 & 30,85 \\
\hline 7 & Lalat & Muscidae & 5 & 2,49 \\
\hline 8 & Pitak & Vespidae & 7 & 3,08 \\
\hline & Jumlah & & $\mathbf{5 6 0}$ & \\
\hline
\end{tabular}

Sumber: Hasil Analisa Data, 2018

Berdasarkan Tabel di atas terlihat bahwa indeks kekayaan jenis serangga tertinggi terdapat pada famili Formicidae sebesar 60,56; selanjutnya diikuti oleh famili Culicidae sebesar 30,85; famili Papilionidae sebesar 5,17; famili Tettigoniidae sebesar 3,64; famili Acrididae dan famili Vespidae masing-masing sebesar 3,08; famili Muscidae sebesar 2,49 dan terendah terdapat pada famili Aeshnidae sebesar 1,82 .

Indeks yang menunjukkan kekayaan jenis suatu komunitas, dimana besarnya nilai ini dipengaruhi oleh banyaknya jenis dan jumlah individu pada areal 
Studi Keanekaragaman Jenis Serangga Daerah Bekas Kebakaran Pada Kawasan Hutan Lindung Bukit Luwit Kecamatan Kelam Permai Kabupaten Sintang

tersebut. Besaran $\mathrm{R}_{1}<3,5$ menunjukkan kekayaan jenis tergolong rendah, $\mathrm{R}_{1}=3,5-5,0$ menunjukkan kekayaan jenis tergolong sedang dan $\mathrm{R}_{1}>5,0$ tergolong tinggi. Beberapa famili serangga yang memiliki nilai indeks kekayaan jenis yang dianggap tinggi adalah Formicidae sebesar 60,56; famili Culicidae sebesar 30,85; dan famili Papilionidae sebesar 5,17. Sedangkan yang tergolong sedang dari famili Tettigoniidae sebesar 3,64 . Untuk famili yang tergolong kekayaan jenis terendah terdapat pada Acrididae dan famili Vespidae masing-masing sebesar 3,08; famili Muscidae sebesar 2,49 dan famili Aeshnidae sebesar 1,82.

\section{Pembahasan}

Di kawasan hutan Lindung Bukit Luwit masih ditemukan area yang memiliki vegetasi dalam kondisi klimaks. Salah satu peran serangga dalam habitat alami adalah sebagai perombak bahan organik tanah dan sebagai makhluk penyeimbang lingkungan alami (Lachat et al., 2006).
Berdasarkan penghitungan Indeks Diversitas (ID) diketahui bahwa Indeks Diversitas tertinggi yaitu spesies Leptocorisa sp dengan nilai ID 0,225. Selanjutnya berturut turut adalah Anopheles sp dengan nilai ID 0,155 ; Acherontia $s p$ dengan nilai ID 0,042; Tenodora $s p$ dengan nilai ID 0,029; Tenodora $s p$ dengan nilai ID 0,024; Glossina sp dengan nilai ID 0,018; dan terendah adalah Aesha sp dengan nilai ID 0,012.

Nilai indeks diversitas tertinggi kurang dari 1 yang hanya berkisar antara $0,012-0,250$ maka tingkat keanekaragaman jenis serangga pada bekas kebakaran Hutan Lindung Bukit Luwit masih tergolong rendah. Hal ini tidak berbeda dengan hasil penelitian pada kawasan hutan bekas kebakaran yang dilakukan di hutan Gunung Gede Pangrango, Jawa Barat dengan nilai indeks keanekaragaman 0,84 pada 409 famili yang ditemukan (Ruslan, 2009).

$\begin{array}{lcr}\text { Semua } & \text { jenis } & \text { serangga } \\ \text { memerlukan } & \text { cahaya } & \text { dalam } \\ \text { kehidupannya. Kondisi } & \text { seperti ini } \\ \text { merupakan tempat yang sesuai untuk } \\ \text { kehadiran berbagai jenis } & \text { serangga. }\end{array}$


Studi Keanekaragaman Jenis Serangga Daerah Bekas Kebakaran Pada Kawasan Hutan Lindung Bukit Luwit Kecamatan Kelam Permai Kabupaten Sintang

Suhu akan mempengaruhi aktivitas serangga, penyebaran, pertumbuhan, dan perkembangbiakan serangga. Sehingga pada areal bekas kebakaran bisa terjadi dominasi jenis tertentu terhadap jenis lainnya. Cahaya diperlukan untuk kehidupannya. Cahaya akan memberikan energi, sehingga dapat menaikkan suhu tubuh dan metabolisme menjadi lebih cepat sehingga mempercepat perkembangan larva (Akutsu et al., 2007).

Berdasarkan hasil analisis indeks nilai keanekaragaman tertinggi 0,225 pada jenis Leptocorisa sp. Tingginya indeks keanekaragaman jenis dan kemerataan jenis serangga tertentu tersebut menunjukkan habitat hutan kurang stabil dibandingkan dengan habitat lainnya dan ketersediaan sumber pakan yang mendukung kehidupan serangga tertentu (Hidayat et al., 2004). Berdasarkan penghitungan densitas atau tingkat kekayaan jenis diketahui bahwa nilai densitas tertinggi yaitu spesies Leptocorisa $s p$ dengan nilai Densitas 60,56; spesies Anopheles sp dengan nilai Densitas 30,85 dan spesies Acherontia sp dengan nilai Densitas 5,17 . Nilai densitas terendah yaitu 1,82 pada spesies Aesha sp.; 2,49 pada spesies Glossina sp; 3,08 pada spesies Leptocarisa sp dan Tenodora $s p$; dan nilai Densitas sedang adalah spesies Tenodora $s p$ dengan nilai 3,64. Dilihat dari nilai densitas, maka Oechopylla smaragdina tergolong spesies yang memiliki kekayaan jenis yang tinggi karna nilai densitas $>$ 5. Untuk nilai densitas dikategorikan sedang bila berada pada kisarana 3,5 - 5. Sedangkan pada spesies yang lain kekayaan jenisnya tergolong rendah karna nilai densitas kurang dari 3,5 yang hanya berkisar antara $0-3,21$.

Keanekaragaman dan kekayaan jenis yang rendah di Kawasan Hutan Lindung Bukit Luwit diduga karena adanya kebakaran hutan. Kebakaran hutan ini sebenarnya telah lama berlangsung akibat tekanan pertambahan penduduk dan pembukaan lahan disekitar kawasan seperti untuk perkebunan kelapa sawit dan perkebunan karet. Hal ini didukung oleh penelitian yang 
Studi Keanekaragaman Jenis Serangga Daerah Bekas Kebakaran Pada Kawasan Hutan Lindung Bukit Luwit Kecamatan Kelam Permai Kabupaten Sintang

dilakukan oleh Gunawan et al., (2010) yang mengatakan bahwa bahwa selama 16 tahun (1990-2006) Provinsi Jawa Tengah telah kehilangan hutan alam lahan kering seluas $446.561,09$ ha atau $88 \%$. Seiring dengan penyusutan luas dan fragmentasi hutan di Jawa Tengah, keanekaragaman dan kekayaan jenis serangga pun semakin terancam.

Berhubungan dengan faktor lingkungan disekitar hutan, pada suhu $29,9{ }^{\circ} \mathrm{C}$, kelembaban $76 \%$ dan intensitas cahaya 24-25 lux merupakan karakteristik lingkungan yang sesuai dengan jenis serangga. Kehadiran suatu jenis serangga dalam suatu habitat dipengaruhi oleh faktor-faktor lingkungan antara lain kemampuan serangga tersebut menyebar, seleksi habitat, kondisi suhu udara, kelembaban udara, kelembaban tanah, cahaya, curah hujan, vegetasi, dan ketersediaan makanan (Brockerhoff et al., 2008).

\section{KESIMPULAN}

1. Indeks keanekaragaman jenis tertinggi terdapat spesies Leptocorisa $s p$ dengan nilai ID
0,225, selanjutnya Anopheles sp dengan nilai ID 0,155; Acherontia $s p$ dengan nilai ID 0,042 ; Tenodora $s p$ dengan nilai ID 0,029; Tenodora $s p$ dengan nilai ID 0,024; Glossina $s p$ dengan nilai ID 0,018; dan terendah adalah Aesha sp dengan nilai ID 0,012 .

2. Dominansi jenis tertinggi terdapat pada jenis spesies Leptocorisa $s p$ dengan nilai 0,538 dan terendah spesies Aesha $s p$ dengan nilai 0,005 .

\section{SARAN}

Penelitian lanjutan dapat dilakukan variasi pengamatan untuk malam hari, antara pukul 05.00-06.00 dan pukul 18.00-19.30, mengingat beberapa jenis serangga aktif pada jam-jam tersebut.

\section{DAFTAR PUSTAKA}

Antonius, Agus S., Amin S. L, Harsuko R. 2018. Ecotourism

Management Strategy of Peat Swamp Forest in Baning Nature Tourist Park Area in 
Studi Keanekaragaman Jenis Serangga Daerah Bekas Kebakaran Pada Kawasan Hutan Lindung Bukit Luwit Kecamatan Kelam Permai Kabupaten Sintang

West Kalimantan Indonesia.

Arief, 2001, Hutan dan Kehutanan. Kanisius. Jakarta.

Mardiastuti A dan Kartono A.P. 2010. Fragmentasi Hutan Alam Lahan Kering di Provinsi Jawa Tengah. Jurnal Penelitian Hutan dan Konservasi Alam. Vol. VII No.1 : 75-91, 2010

Hidayat; Otong; Sutarno; Nono; Suhara; Sanjaya dan Yayan. 2004. DasarDasar Entomologi. Bandung: Universitas Pendidikan Indonesia.

Oka, I.N., 1995, Pengendalian Hama Terpadu dan Implementasinya di indonesia. Universitas Gadja Mada-Press. Yokyakarta.
Patang F. 2010. Keanekaragaman

Takson Serangga pada Areal Hutan Bekas Tambang Kutai Kartanegara, Kalimantan Timur. Bioprospek. Vol.7 (1): 80-89pp

Perum Perhutani. 2006. Statistik Perum Perhutani Tahun $20012005 . \quad$ Direksi Perum Perhutani. Jakarta.

Putra, N.S., 1994, Serangga di sekitar kita. Kanisius. Yokyakarta.

Umar, R., 2010, Penuntun Praktikum Ekologi Umum. Universitas Hasanuddin. Makassar.

Untung, K., 1996, Pengantar Pengelolaan Hama Terpadu. Universitas Gadja Mada-press. Yokyakarta. 